\title{
In de spreekkamer is parate kennis belangrijker dan opzoekkennis*
}

\author{
H.J.M. van Rossum
}

In de spreekkamer moet de arts het doen met zijn parate kennis. De interactie met patiënten wordt van de zijde van de arts inhoudelijk vooral gevoed door kennis, deels bewust, deels onbewust. Een enkele keer zoekt de arts informatie op, omdat hij of zij die niet paraat wil of kan hebben. Bij het lezen van specialistenbrieven zal hij wellicht soms even iets nazoeken, maar tijdens het spreekuur draait het alleen om parate kennis.

Twee kernprocessen neem ik nader onder de loep: het diagnostisch proces tijdens het afnemen van de anamnese en het uitleggen van de bevindingen aan de patiënt.

Tijdens de eerste fase van het consult, de probleemverkenning, speurt de arts naar aanwijzingen in het verhaal en het lichaam van de patiënt die de aard van de aandoening moeten opleveren en de fase waarin de aandoening is beland. Het is een zoekproces dat grotendeels automatisch en onbewust verloopt op basis van een kennisnetwerk dat de arts in de loop van jaren heeft opgebouwd op grond van studie, voorbeelden, ervaringen, fouten en reflectie op die fouten. Dit kennisnetwerk, eigenlijk een 'kennisautomaat', stelt hem of haar in staat het gros van de problemen waarmee patiënten zich presenteren, te benoemen als diagnosen en te plaatsen op het tijdspad waarop het ziektebeeld zich ontwikkelt.

Dezelfde paratekennisautomaat waarschuwt ook wanneer de arts geen vat krijgt op het probleem. De automaat slaat alarm en wordt dan als het ware geopend en paraat gemaakt voor het verwoorden van een meer bewuste zoekstrategie: de patiënt verwijzen, terug laten komen of het probleem verder uitzoeken. ${ }^{1}$ Het is echter het paratekennisnetwerk dat de detectie verricht en de vervolgacties in gang zet. Het uitzoeken gebeurt buiten de spreekkamer.

$\mathrm{Na}$ de anamnese en het lichamelijk onderzoek volgt een fase waarin de arts uitleg geeft aan de patiënt of diens familie; hij of zij legt als het ware verantwoording af over het resultaat dat de kennisautomaat heeft verschaft. Dit proces vindt plaats tussen arts en patiënt, via de taal, en moet dus bewust verlopen. Ook hierin maakt de arts gebruik van parate kennis; alle elementen van zijn verhaal krijgen een naam in een logisch verband. Waar de kennisautomaat vrijwel uitsluitend werkt met labels van klinische ziektebeelden, maakt de arts nu ook gebruik van basale kennis om de verhalende uitleg begrijpelijk te maken. Het opzoeken van enkele details kan nodig zijn, bijvoorbeeld de dosering of de bijwerking van een geneesmiddel; ook het gebruik van tekeningen en modellen kan de uitleg ondersteunen. Maar de lijn van het verhaal moet ad hoc geconstrueerd worden op grond van parate kennis.

Het resultaat van de kennisautomaat is afhankelijk van de kwaliteit ervan. Blinde vlekken, recente spectaculaire casuïstiek, ${ }^{2}$ gemaakte fouten ${ }^{3}$ en verouderde kenniselementen in het netwerk zorgen voor ver-

* Dit artikel verschijnt ook in het Nederlands Tijdschrift voor Geneeskunde. 
keerde uitkomsten of onvoldoende alarmsignalen. Het is dus de plicht van de arts het kennisnetwerk voortdurend te testen en te onderhouden, alleen en met collega's. Dit kost tijd, waarin de arts studeert, leest en casuïstiek bespreekt met collega's. Dan wordt nieuwe informatie omgezet in kennis. Maar dat gebeurt buiten de spreekkamer.

\section{Literatuur}

1. Boshuizen HPA, Schmidt HG. De ontwikkeling van medische expertise; implicaties voor het praktisch en theoretisch medisch onderwijs. In: Metz JCM, Scherpbier AJJA, Vleuten CPM van der, editors. Medisch onderwijs in de praktijk. Assen: Van Gorcum; 1995. p. 25-39.
2. Rossum HJM van, Bender W, Meinders AE. De invloed van biografische details in casuïstische mededelingen op het diagnostisch oordeel. Ned Tijdschr Geneeskd. 1991;135:802-5.

3. Bordage G. Why did I miss the diagnosis? Some cognitive explanations and educational implications. Acad Med 1999;74(10 Suppl);S138-43.

De auteur:

Prof. dr. H.J.M. van Rossum is arts.

Correspondentiedres:

Prof. dr. H.J.M. van Rossum, VU Medisch Centrum, Onderwijsinstituut, Postbus 7057, 1007 MB Amsterdam, hjm.vanrossum@vumc.nl.

\section{Summary}

Ready knowledge rules the consultation room - there is no time to look things up. The doctor attempts to find the diagnosis on the basis of a network of ready knowledge. The quality of this knowledge network determines the quality of the resultant diagnosis and of the subsequent treatment. The doctor must continually test and maintain his or her knowledge network. (Rossum HJM van. In the consultation room, ready knowledge is more important than knowledge that must be looked up. Dutch Journal of Medical Education 2006;25(1):41-42.) 